\title{
The Effectiveness of eBook versus Printed Books in the Rural Schools in Indonesia at the Modern Learning Era
}

\author{
Tri Nugroho Budi Santoso ${ }^{1}$, Siswandari ${ }^{2}$, Hery Sawiji ${ }^{3}$
}

\begin{tabular}{l} 
ARTICLE INFO \\
\hline Article History: \\
Received 07.07.2018 \\
Received in revised form \\
14.08 .2018 \\
Accepted \\
Available online 01.10 .2018
\end{tabular}

\begin{abstract}
This article is an advanced research from previous research, which aimed to test the use of eBooks and printed books in the schools outside urban areas. This study employed a quantitative approach, using the General Linear Model (GML) through Univariate analy sis technique. The data-collection Instruments were the students' learning outcomes' documents. The data obtained were processed using IBM SPSS Statistic 21 . The results showed the value of $\operatorname{Sig}(0.000)<\alpha(0.05)$ so that H0 is rejected. Hence, there is an influence of teaching materials on the students' learning outcomes. Covariant analysis results in column B by 5.573 points showed that the learning outcomes of the students who usedeBooks were higher by 5.573 points than those using printed books. This study employs that rural schools also experience the impact of digitalization era in the modern learning era, as evidenced by the effectiveness of using eBooks which is higher than that of using printed books. Limited facilities are not the main thing in improving the quality of learning.
\end{abstract}

Keywords:

C 2018 IJERE. All rights reserved

eBook, printed book, modern learning

eBook, printed book, modern learning

\section{INTRODUCTION}

Teaching materials are important in the learning process. Adequate learning resources will be able to complement, maintain, and enrich the learning process itself (Darmawan, 2012: 43). Currently, learning materials also continue to experience development due to technological advances. The growing development of electronic references that are easy to use and very useful has a strong contribution to the development of digital literacy (Epps, 2005: 287; Medeiros, 2010: 229). Digital literacy is a form of literacy development that is oriented to the challenges of the times when it needs the ethics of the digital community to manage the information obtained (Brown, 2014: 280).

Digital literacy is very necessary because the learning process can occur anywhere and anytime. In addition to the development of increasingly sophisticated smartphones, students can learn they materials they want quickly. eBooks are very popular learning media that students use today. The increasing popularity of eBooks began with the spread of mobile reader devices that can facilitate the reading of digital books at the end of the first decade of the twenty-first century (Sehn and Fragoso, 2015: 401). eBooks as transformations from traditional books to digital forms make it easy for students to search for available information (Wang \& Yang, 2014: 2); (Ratna, 2012: 7). Koh \& Herring (2016: 764) eBooks have a variety of advantages over current printed books. They are easy to access, no need to go to the library, easy topic search, can be accessed anywhere and anytime, display is better, cheaper and saves space deviation. Yachina, Valeeva, \& Sirazeeva (2016: 434) added that the characteristic feature of the use of electronic teaching materials compared to traditional methods of education is to provide information not only in the form of text, but also through audio visuals so as to enable students to focus on learning and contribute to better understanding and storage of information.

Based on a survey conducted by Vserv's smart data platform for mobile marketing and commerce (2015), around $20 \%$ of smartphone users in Indonesia are said to consume large quota data, around $249 \mathrm{MB} /$ day, which are categorized as data enthusiasts. The quote data are mostly used to install applications and games on their smartphones. Then, how do rural communities respond this? Can students in rural areas also utilize digital literacy to maximize their learning? Or is the printed book the only lear ning material they can use? 
Santoso,T.N.B., , Siswandari, Sa wiji,H.(2018). The effectiveness of e book versus printed books in the ru ral schools in indonesia at the modern learning era. International Journal of Educational Research Review, 3(4),77-84.

Fauzie (2018) World Bank said that the quality of education in Indonesia was still low, although the expansion of access to education for the public was considered to have increased significantly. This condition is certainly a concern for all people to be able to improve the quality of education in Indonesia.

\section{Situation of the Problem}

Although gab occurs in the urban and rural schools, technological sophistication and learning media are now also experienced by all people both in urban and outside urban areas (Christoph, Enrico, and Alison, 2013: 34). However, rapid technological development cannot necessarily be followed in all parts of Indonesia. There are still many schools that experience the gab in mastering technology. Many factors inhibit this from students' digital literacy skills to the availability of learning facilities, to form learning habits to increase knowledge and change students from not knowing (Hidayati \& Ismail, 2018:74)

Are rural schools able to follow modern learning patterns in the digital era today? eBooks and printed books are two of the media that can measure this. In general, the community will understand that the printed book is the right learning material for the rural community due to various facilities or even inherent culture (Jana, 2014: 508). How ever, the researchers ascertained whether the printed book was still the main learning source.

\section{Aim of the Study}

Based on the actual dynamics of the development and conditions, it was interesting to test the effectiveness of the right teaching materials in rural schools in Indonesia, and vocational school 1 Banyudono is the right place to do research. This article answered the question through the results of the statistical data in the field.

\section{METHOD}

This study employed a quantitative approach, using the General Linear Model (GML) with Univariate analysis technique. Univariate analysis is a regression analysis and a variation of one dependent variable with two or more factor variables or other variables. The research subjects were the vocational students in the Banyudono area, Boyolali Regency, Indonesia which were taken by purposive sampling as many as 64 from a total population of 320 students in 12 th grade. .

\section{Material}

The data collection was undertaken through tests after learning with eBooks in the experimental class and printed book in the control class. The test items used have undergone a reliability test consisting of 20 valid items.

\section{Data Analyses}

The results of data collection were processed using IBM SPSS Statistics 21 and described using descriptive and critical analyses.

\section{FINDINGS}

\section{Test Validity}

The test validity was found out by using the Pearson formula of product moment correlation. The validity testing criteria $w$ as if $r_{\text {count }}>r_{\text {table }} w$ ith a significance level of 0.05 , the instrument $w$ as valid. On the contrary, if $r_{\text {count }}>r_{\text {table, the instrument }} w$ as invalid.

The results of the validity test of 20 questions, and the 20 items with $r_{\text {count }}>r$ table were valid. Valid items had easy, medium, and difficult difficulty indexes, consisting of 3 items in the easy category, 14 items in the medium category, and 2 items in the difficult category. In this case, the discriminating power was moderate and good. Alpha reliability coefficient was 0.8812 which means that the test-item reliability is categorized as very high (attached in attachment on table 7).

\section{Fixed Factor Variable}


Santoso,T.N.B., , Siswandari , Sa wiji,H.(2018). The effectiveness of e book versus printed books in the ru ral schools in indonesia at the modern learning era. International Journal of Educational Research Review, 3(4),77-84.

Table 1 Between-Subject Factors

\begin{tabular}{|c|c|c|c|}
\hline & & $\begin{array}{c}\text { Value } \\
\text { Label }\end{array}$ & $\mathbf{N}$ \\
\hline \multirow{2}{*}{$\begin{array}{l}\text { teaching } \\
\text { materials }\end{array}$} & 1 & eBook & 32 \\
\hline & 2 & Print Book & 32 \\
\hline
\end{tabular}

Table 1 describes the Fixed Factor variable. There were two groups, namely the group of 32 students which used eBooks and that which used printed books.

\section{Interaction Test Results}

Table 2 Tests of Between-Subjects Effects

\section{Dependent Variable: final learning outcomes}

\begin{tabular}{lllllll}
\hline Source & $\begin{array}{l}\text { Type III Sum } \\
\text { of Squares }\end{array}$ & & Mean Square & F & Sig. & $\begin{array}{c}\text { Partial } \\
\text { Squared }\end{array}$ \\
\hline Corrected Model & 2813,429 a & 3 & 937,810 & 41,758 &, 000 &, 676 \\
\hline Intercept & 4656,457 & 1 & 4656,457 & 207,336 &, 000 &, 776 \\
\hline teaching_materials & 134,084 & 1 & 134,084 & 5,970 &, 018 &, 090 \\
\hline pre_test & 2174,464 & 1 & 2174,464 & 96,822 &, 000 &, 617 \\
\hline $\begin{array}{l}\text { teaching_materials } \\
\text { pre_test }\end{array}$ & 57,308 & 1 & 57,308 & 2,552 &, 115 &, 041 \\
\hline Error & & & & & & \\
\hline Total & 1347,508 & 60 & 22,458 & & & \\
\hline Corrected Total & 380850,000 & 64 & & & &
\end{tabular}

a. R Squared = ,676 (Adjusted R Squared $=, 660)$

Table 2 describes the Tests of Between-Subjects Effects. In the teaching material row, the Sig value of pre-test was $0.115>\alpha(0.05)$; then, $\mathrm{H}_{0}$ is accepted. So, there is no interaction between teaching materials and the pre-test. Then, covariance analysis was carried out.

Table 3 Descriptive Statistics

\begin{tabular}{cccc}
\hline \multicolumn{3}{c}{ Dependent Variable: } & \multicolumn{3}{l}{ final learning outcomes } \\
\hline $\begin{array}{c}\text { teaching } \\
\text { materials }\end{array}$ & Mean & $\begin{array}{c}\text { Std. } \\
\text { Deviation }\end{array}$ & $\mathrm{N}$ \\
\hline eBook & 79,84 & 7,238 & 32 \\
\hline Print Book & 73,59 & 7,853 & 32 \\
\hline Total & 76,72 & 8,127 & 64
\end{tabular}

Table 3 is a descriptive statistic of the dependent variable, the learning outcomes after the implementation of the learning material. The average score of the students who used eBooks was 79.84, while that of the students who used printed books was lower at 73.59. The variants for the two groups are almost the same which can be seen through the following Levene's test:

Table 4 Levene's Test of Equality of Error Variances

\begin{tabular}{cccc}
\hline \multicolumn{2}{c}{ Dependent Variable: } & \multicolumn{3}{c}{ final learning outcomes } \\
\hline F & df1 & df2 & Sig. \\
\hline, 384 & 1 & 62 &, 538 \\
\hline
\end{tabular}


Santoso,T.N.B., , Siswandari , Sa wiji,H.(2018). The effectiveness of e book versus printed books in the ru ral schools in indonesia at the modern learning era. International Journal of Educational Research Review, 3(4),77-84.

\section{Tests the null hypothesis that the error variance of the dependent variable is equal across groups.}

\section{a. Design: Intercept + pre_test + teaching_materials}

The value of $\operatorname{Sig}(0.538)>\alpha(0.05)$ so that $\mathrm{H}_{0}$ is accepted. Thus, the variants between the two groups are the same.

Table 5 Tests of Between-Subjects Effects

\begin{tabular}{lllllll}
\hline Dependent Variable: & final learning outcomes & & & \\
\hline Source & $\begin{array}{l}\text { Type III Sum } \\
\text { of Squares }\end{array}$ & $\mathrm{df}$ & Mean Square & $\mathrm{F}$ & Sig. & $\begin{array}{l}\text { Partial } \\
\text { Squared }\end{array}$ \\
\hline Corrected Model & $2756,121^{\mathrm{a}}$ & 2 & 1378,061 & 59,838 &, 000 &, 662 \\
\hline Intercept & 4752,656 & 1 & 4752,656 & 206,370 &, 000 &, 772 \\
\hline pre_test & 2131,121 & 1 & 2131,121 & 92,538 &, 000 &, 603 \\
\hline $\begin{array}{l}\text { teaching_material } \\
\text { s }\end{array}$ & 495,312 & 1 & 495,312 & 21,507 &, 000 &, 261 \\
\hline Error & 1404,816 & 61 & 23,030 & & & \\
\hline Total & 380850,000 & 64 & & & & \\
\hline Corrected Total & 4160,938 & 63 & & & & \\
\hline
\end{tabular}

a. R Squared = ,662 (Adjusted R Squared $=, 651$ )

In table 5 Test of Between-Subjects Effects, the hypothesis testing of the effect of teaching materials on the learning outcomes can be conducted.

Hypotheses:

$\mathrm{H}_{0}=$ there is no difference of using eBooks or printed books.

$\mathrm{H}_{1}=$ there are different learning outcomes of using eBooks and printed books.

Sig value $(0.000)<\alpha(0.05)$; then, $\mathrm{H}_{0}$ is rejected. So there are differences in the learning outcomes of using eBooks and printed books.

\section{Covariant Analysis Results}

Table 6 Parameter Estimates

\section{Dependent Variable: final learning outcomes}

\begin{tabular}{|c|c|c|c|c|c|c|c|}
\hline \multirow[t]{2}{*}{ Parameter } & \multirow[t]{2}{*}{ B } & \multirow{2}{*}{$\begin{array}{l}\text { Std. } \\
\text { Error }\end{array}$} & \multirow[t]{2}{*}{$\mathrm{t}$} & \multirow[t]{2}{*}{ Sig. } & \multicolumn{2}{|c|}{$95 \%$ Confidence Interval } & \multirow{2}{*}{$\begin{array}{c}\text { Partial Eta } \\
\text { Squared }\end{array}$} \\
\hline & & & & & $\begin{array}{l}\text { Lower } \\
\text { Bound }\end{array}$ & $\begin{array}{l}\text { Upper } \\
\text { Bound }\end{array}$ & \\
\hline Intercept & 43,487 & 3,243 & 13,411 & ,000 & 37,003 & 49,971 & ,747 \\
\hline pre_test &, 541 & 056 & 9,620 & ,000 & 429 & 654 & 603 \\
\hline [teaching_materials=1] & 5,573 & 1,202 & 4,638 & 000 & 3,170 & 7,977 & 261 \\
\hline
\end{tabular}

a. This parameter is set to zero because it is redundant.

Column B and Sig mean that if the learning outcomes of the students using eBooks will be 5,573 points higher than those of the students using printed books. This is supported by the value of $\operatorname{Sig}(0.000)<\alpha(0.05)$; then, $\mathrm{H}_{0}$ is rejected. Therefore, there is the influence of teaching materials on the students' learning outcomes. 
Santoso,T.N.B., , Si swandari , Sa wiji,H.(2018). The effectiveness of e book ve rsus printed books in the ru ral schools in indonesia at the modern learning era. International Journal of Educational Research Review, 3(4),77-84.

This is in line with the research conducted by Ukwoma, S. C., Iwundu, N. E., and Iw undu, I. E. (2016: 702) in their article entitled "Digital literacy skills possessed by students of UNN, implications for effective learning and performance: The study of the MTN Universities Connect Library "published in the New Library Wor ld which explained that various forms of digital literacy can affect students' academic performance. Pun, R. (2015: 134) in his article entitled "Conceptualizing the integration of digital humanities in instructional services: Possibilities to enhance digital literacy in the $21^{\text {st }}$ century" published by Library Hi Tech explained that digital resources are positively correlated with the improvement of students' learning through library instructional services.

\section{RESULT, DISCUSSION, AND SUGGESTIONS}

The results showed that the Sig value $(0.000)<\alpha(0.05)$; then, H0 is rejected. Therefore, there is the influence of teaching materials on the students' learning outcomes. Column B and eBook Sig shows the range of 5.573 points which means that if students use eBooks, their learning outcomes will be higher by 5.573 points compared to those using printed books. It can be concluded that the use of eBooks in rural schools is able to further improve students' learning outcomes compared to the use of printed books. Some of the studies that support these findings are those of Lai (2016), Liaw \& Huang (2014), Chen (2013), Bradshaw (2005), Goodwin (2014), Woo (2011), Massis (2010), Bronshteyn (2007), deNoyelles \& Seilhamer (2013), Tucker (2012), Letchumanan \& Muniandy (2016), Rojeski (2012), and Parkes (2007). The results that contradict these findings explain that the printed book is still relevant (Jeong, 2012; Katsarska, 2005; Lewellen, Bischof, \& Plum, 2016; Nwagwu \& Okafor, 2014; Sehn \& Fragoso, 2015; Darsono, Winarno, \& Slamet, 2018). This finding is indeed an interesting thing. Despite all the limitations in rural schools, they are able to apply modern learning resources. Kouis \& Konstantinou (2014:531) explain that eBooks can replace printed books but not in the near future. It takes a lot of preparation from various parties to be able to maximize the use of eBooks.

There are many supporting factors from the research findings, one of which is an increase in internet facilities in various local areas. The results of the researchers' survey also show that all students have their own gadgets to support their daily activities. Christoph, Enrico, and Alison (2013:34) explains that internet facilities are becoming determinants of the development of digital literacy skills in a region. Therefore, the underdeveloped area is not a reason for a teacher in facilitating modern learning. In addition to the internet facilities, various kinds of eBook advantages also facilitate students in learning activities. Kumbhar (2012: 777) adds that an increase in the use of eBooks is due to the user ease, cost, and portability. The availability of teaching materials and learning facilities in rural schools is certainly not comparable to that in urban schools. Therefore, the creativity and quality of the teacher's teaching is the main key to overcome the limitations of this facility (Duman \& Karagöz, 2016:1). Garba, et al. (2013: 35) explains that teachers are the main factor that continues to be developed for that it requires adequate infrastructure development in an effort to improve learning. The gadget facility owned by students must be used as a medium for learning.

For the world of education in the future, it is suggested that the development of electronic teaching materials can also be the homew ork of teachers and all school components in order to improve the quality of learning in schools, especially in underdeveloped areas. The development of eLibrary can also be a more efficient solution (Bronshteyn, 2007: 560).

\section{REFERENCES}

Bradshaw. (2005). Multimedia textbooks and student learning. MERLOT Journal of Online Learning and Teaching, 1 (2), 1-9.

Bronshteyn, K. (2007). Using NetLibrary eBooks at the reference desk. Reference Services Review, 35 (4), 560570 .

Brown, S. A. (2014). Conceptualizing digital literacies and digital ethics for sustainability education. International Journal of Sustainability in Higher Education, 15 (3), 280-290. 
Santoso,T.N.B., , Siswandari , Sa wiji,H.(2018). The effectiveness of e book versus printed books in the rural schools in indonesia at the modern learning era. International Journal of Educational Research Review, 3(4),77-84.

Chen, H. Y. (2013). Exploring the reasons for using electric books and technologic pedagogical and content knowledge of taiw anese elementary mathematics and science teachers. Journal TOJET: Educational Technology, 12 (2), 131-141.

Christoph, S., Enrico, C., \& Alison, G. (2013). Internet going mobile: internet access and use in 11 African countries. Info, 15 (5), 34-51.

Darmawan, D. (2012). Inovasi Pendidikan: Pendekatan Praktik Teknologi Multimedia dan Pembelajaran Online. Bandung: PT Remaja Rosdakarja.

Darsono, Winarno, \& Slamet, S. T. Y. (2018). The need textbook w riting of children's story based on character education. International Journal of Educational Research Review, 3 (2), 1-8.

deNoyelles, A., \& Seilhamer, R. (2013). E-textbook access, usage, and beliefs: Implications for adoption in higher education. Journal of Applied Research in Higher Education, 5 (2), 189-201.

Duman, T. \& Karagöz, S. (2016). An evaluation of turkish teacher education system compared to other models in different countries. International Journal of Educational Research Review, 1 (1), 1-13.

Epps, A. S. V. (2005). The evolution of electronic reference sources. Library Hi Tech, 23 (2), 287-298.

Fauzie, Y. Y. (2018). https://www.cnnindonesia.com/gaya-hidup/20180607113429-284-304214/bank-dunia-kualitaspendidikan-indonesia-masih-rendah, accessed on August 1, 2018

Goodwin, C. (2014). The e-Duke scholarly collection: E-book v. print use. Collection Building, 33 (4), 101-105.

Hidayati, A. \& Ismail (2018). Strategies to improve student learning habits for middle school student in Sukoharjo, Indonesia. International Journal of Educational Research Review, 3 (3), 74-79.

Jana, M. (2014). Comparing electronic short books from the USA and the UK to South Africa: Can they be successful in the South African trade book sector?. The Electronic Library, 32 (4) 4, 508-521.

Jeong, H. (2012). A comparison of the influence of electronic books and paper books on reading comprehension, eye fatigue, and perception. The Electronic Library, 30 (3), 390-408.

Katsarska, M. (2005). Reading text books interculturally, helpdesk for intercultural evaluation of learning materials. Managerial Law, 47 (3/4), 159-168.

Koh, H. S. \& Herring, S. C. (2016). Historical insights for ebook design. Library Hi Tech, 34 (4),764-786.

Kouis, D. \& Konstantinou, N. (2014). Electronic textbooks advantages and challenges for the Hellenic higher education and publishing community. Library Review, 63 (6/7), 531-543.

Kumbhar, R. (2012). E-books: Review of research and writing during 2010. The Electronic Library, 30 (6), 777795.

Lai, C. (2016). Integrating E-Books into science teaching by preservice elementary school teachers. Journal of Education in Science: Environment and Health (JESEH). 2 (1), 57-66.

Letchumanan, M., \& Muniandy, B. (2016). How mathematics postgraduate students use mobile e-book? Library Hi Tech News, 33 (7), 6-7.

Lewellen, R., Bischof, S., \& Plum, T. (2016). EBL ebook use compared to the use of equivalent print books and other eresources: A University of Massachusetts Amherst - MINES for Libraries ${ }^{\circledR}$ case study. Performance Measurement and Metrics, 17 (2), 150-164.

Liaw \& Huang (2014). Investigating learner attitudes tow ard e-books as learning tools: Based on the activity theory approach. Journal Interactive Learning Environments. 1 (1), 1-15.

Massis, B. E. (2010). E-book readers and college students. New Library World, 111 (7/8), 347-350.

Medeiros, N. (2010). Every (e)book its (e)reader: book collections at a crossroads.OCLC Systems \& Services: International digital library perspectives, 26 (4), 229-231.

Nwagwu, W. E. \& Okafor, J. L. (2014). Diffusion of ebooks among postgraduate students of the University of Ibadan, Nigeria. Library Review, 63 (1/2), 86-109. 
Santoso,T.N.B., , Siswandari , Sa wiji,H.(2018). The effectiveness of e book versus printed books in the ru ral schools in indonesia at the modern learning era. International Journal of Educational Research Review, 3(4),77-84.

Parkes, D. (2007). E-books from ebrary at Staffordshire University: A case study. Program, 41 (3), 253-261.

Rojeski, M. (2012). User perceptions of ebooks versus print books for class reserves in an academic library.Reference Services Review, 40 (2), 228-241.

Sehn, T. C. M. \& Fragoso, S. (2015). The synergy between eBooks and printed books in Brazil. Online Information Review, 39 (3), 401-415.

Sehn, T. C. M., \& Fragoso, S. (2015). The synergy between eBooks and printedbooks in Brazil. Online Information Review, 39 (3), 401-415.

Tucker, J. C. (2012). Ebook collection analysis: subject and publisher trends. Collection Building, 31 (2), 40-47.

Vserv, https://www.vserv.com/vserv-unveils-first-smartphone-userpersona-report-supr-Indonesia/_diakses tanggal 1 agustus 2018

Woo, T. K. (2011). Developing quality learning materials for effective teaching and learning in an ODL environment: Making the jump from print modules to online modules. Asian Association of Open Universities Journal, 6 (1), 51-58.

Yachina, N. P., Valeeva, L. A., \& Sirazeeva, A. F. (2016). E-teaching materials as the means to improve humanities teaching proficiency in the context of education informatization. International Journal of Environmental \& Science Education, 11 (4), 433-442. 


\section{ATTACHMENT}

Table 7 test item analysis

\begin{tabular}{|c|c|c|c|c|c|c|c|c|c|c|c|c|c|c|c|c|c|c|c|c|}
\hline Test Number & 1 & 2 & 3 & 4 & 5 & 6 & 7 & 8 & 9 & 10 & 11 & 12 & 13 & 14 & 15 & 16 & 17 & 18 & 19 & 20 \\
\hline $\begin{array}{l}\text { Number of } \\
\text { Correct } \\
\text { Answers }\end{array}$ & 15 & 12 & 13 & 13 & 9 & 15 & 5 & 10 & 6 & 11 & 12 & 5 & 11 & 13 & 12 & 8 & 12 & 10 & 15 & 13 \\
\hline r count & 0,506 & 0,858 & 0,479 & 0,594 & 0,477 & 0,527 & 0,506 & 0,585 & 0,578 & 0,643 & 0,466 & 0,675 & 0,680 & 0,498 & 0,541 & 0,466 & 0,709 & 0,713 & 0,527 & 0,479 \\
\hline & 8 & 6 & 3 & 3 & 9 & 9 & 8 & 2 & 7 & 3 & 6 & 7 & 1 & 4 & 3 & 6 & 3 & 2 & 9 & 3 \\
\hline r table & 0,443 & 0,443 & 0,443 & 0,443 & 0,443 & 0,443 & 0,443 & 0,443 & 0,443 & 0,443 & 0,443 & 0,443 & 0,443 & 0,443 & 0,443 & 0,443 & 0,443 & 0,443 & 0,443 & 0,443 \\
\hline & 8 & 8 & 8 & 8 & 8 & 8 & 8 & 8 & 8 & 8 & 8 & 8 & 8 & 8 & 8 & 8 & 8 & 8 & 8 & 8 \\
\hline Validity & $\mathrm{V}$ & V & V & V & V & V & V & V & V & V & V & V & V & V & V & V & V & V & V & V \\
\hline Variant & 0,20 & 0,25 & 0,24 & 0,24 & 0,26 & 0,20 & 0,20 & 0,26 & 0,22 & 0,26 & 0,25 & 0,20 & 0,26 & 0,24 & 0,25 & 0,25 & 0,25 & 0,26 & 0,20 & 0,24 \\
\hline p & 0,75 & 0,60 & 0,65 & 0,65 & 0,45 & 0,75 & 0,25 & 0,50 & 0,30 & 0,55 & 0,60 & 0,25 & 0,55 & 0,65 & 0,60 & 0,40 & 0,60 & 0,50 & 0,75 & 0,65 \\
\hline$q$ & 0,25 & 0,40 & 0,35 & 0,35 & 0,55 & 0,25 & 0,75 & 0,50 & 0,70 & 0,45 & 0,40 & 0,75 & 0,45 & 0,35 & 0,40 & 0,60 & 0,40 & 0,50 & 0,25 & 0,35 \\
\hline $\mathrm{pq}$ & 0,19 & 0,24 & 0,23 & 0,23 & 0,25 & 0,19 & 0,19 & 0,25 & 0,21 & 0,25 & 0,24 & 0,19 & 0,25 & 0,23 & 0,24 & 0,24 & 0,24 & 0,25 & 0,19 & 0,23 \\
\hline Difficulty & 0,75 & 0,60 & 0,65 & 0,65 & 0,45 & 0,75 & 0,25 & 0,50 & 0,30 & 0,55 & 0,60 & 0,25 & 0,55 & 0,65 & 0,60 & 0,40 & 0,60 & 0,50 & 0,75 & 0,65 \\
\hline Information & easy & $\begin{array}{l}\text { medi } \\
\text { um }\end{array}$ & $\begin{array}{l}\text { medi } \\
\text { um }\end{array}$ & $\begin{array}{l}\text { medi } \\
\text { um }\end{array}$ & $\begin{array}{l}\text { medi } \\
\text { um }\end{array}$ & easy & $\begin{array}{c}\text { diffic } \\
\text { ult }\end{array}$ & $\begin{array}{l}\text { medi } \\
\text { um }\end{array}$ & $\begin{array}{c}\text { diffic } \\
\text { ult }\end{array}$ & $\begin{array}{l}\text { medi } \\
\text { um }\end{array}$ & $\begin{array}{l}\text { medi } \\
\text { um }\end{array}$ & $\begin{array}{c}\text { diffic } \\
\text { ult }\end{array}$ & $\begin{array}{l}\text { medi } \\
\text { um }\end{array}$ & $\begin{array}{l}\text { medi } \\
\text { um }\end{array}$ & $\begin{array}{l}\text { medi } \\
\text { um }\end{array}$ & $\begin{array}{l}\text { medi } \\
\text { um }\end{array}$ & $\begin{array}{l}\text { medi } \\
\text { um }\end{array}$ & $\begin{array}{l}\text { medi } \\
\text { um }\end{array}$ & easy & $\begin{array}{l}\text { medi } \\
\text { um }\end{array}$ \\
\hline $\begin{array}{c}\text { True Amount } \\
\text { Up }\end{array}$ & 9 & 10 & 8 & 8 & 7 & 9 & 5 & 7 & 6 & 9 & 8 & 5 & 9 & 8 & 8 & 6 & 10 & 9 & 9 & 9 \\
\hline $\begin{array}{c}\text { True Amount of } \\
\text { Down }\end{array}$ & 6 & 2 & 5 & 5 & 2 & 6 & 0 & 3 & 0 & 2 & 4 & 0 & 2 & 5 & 4 & 2 & 2 & 1 & 6 & 4 \\
\hline $\begin{array}{l}\text { Differential } \\
\text { Power Test }\end{array}$ & 0,30 & 0,80 & 0,30 & 0,30 & 0,50 & 0,30 & 0,50 & 0,40 & 0,60 & 0,70 & 0,40 & 0,50 & 0,70 & 0,30 & 0,40 & 0,40 & 0,80 & 0,80 & 0,30 & 0,50 \\
\hline $\begin{array}{l}\text { Differential } \\
\text { Power Test } \\
\text { Information }\end{array}$ & $\begin{array}{l}\text { medi } \\
\text { um }\end{array}$ & $\begin{array}{l}\text { very } \\
\text { well }\end{array}$ & $\begin{array}{l}\text { medi } \\
\text { um }\end{array}$ & $\begin{array}{l}\text { medi } \\
\text { um }\end{array}$ & good & $\begin{array}{l}\text { medi } \\
\text { um }\end{array}$ & good & $\begin{array}{l}\text { medi } \\
\text { um }\end{array}$ & good & good & $\begin{array}{l}\text { medi } \\
\text { um }\end{array}$ & good & good & $\begin{array}{l}\text { medi } \\
\text { um }\end{array}$ & $\begin{array}{l}\text { medi } \\
\text { um }\end{array}$ & $\begin{array}{l}\text { medi } \\
\text { um }\end{array}$ & $\begin{array}{l}\text { very } \\
\text { well }\end{array}$ & $\begin{array}{l}\text { very } \\
\text { well }\end{array}$ & $\begin{array}{l}\text { medi } \\
\text { um }\end{array}$ & good \\
\hline Reliability & \multicolumn{20}{|c|}{$0,8812=$ reliabel $(0,8812>0,4438)$} \\
\hline Test Criteria & YES & YES & YES & YES & YES & YES & YES & YES & YES & YES & YES & YES & YES & YES & YES & YES & YES & YES & YES & YES \\
\hline
\end{tabular}

